\title{
Gut Microbiota and Immune Responses
}

\section{Tobin Lee*}

ImmuPharmar Co., Chicago, IL 60690, USA

*: All correspondence should be sent to: Dr. Tobin Lee.

Author's Contact: Tobin Lee, PhD, E-mail: tobinlee@impharmar.com

DOl: https://doi.org/10.15354/si.22.re022

The author declares no competing interest.

The gut is the body's largest immune organ, consisting of both hematopoietic (macrophages, dendritic cells, and $\mathrm{T}$ cells) and non-hematopoietic cells (epithelial cells, Paneth cells, and goblet cells). It is home to hundreds of millions of microorganisms, which collaborate with the host immune system to maintain the internal environment's homeostasis. The gut microbiome plays a critical role in the development of inflammatory responses (including autoimmune diseases, allergies, etc.). The gut microbiota has a direct effect on the maturation of the host immune system, inducing immunoglobulin $A(\lg A)$, and regulating $C D 4^{+} \mathrm{T}$ cells, including Th1, Th17, and regulatory $\mathrm{T}$ cells $\left(\mathrm{CD}^{+}, \mathrm{CD}^{+} 5^{+}\right.$, Foxp3 $\left.3^{+}\right)$. Along with the expression of antimicrobial peptides (AMPs), numerous molecules produced by flora may influence these immune responses. Numerous basic and clinical studies have established that controlling the gut microbiota is an effective method for treating and controlling disease. Once these mechanisms are fully understood, probiotics/prebiotics may be used to regulate the gut microbiota in order to treat diseases.

Keywords: Gut; Microbiota; Host Immunity; Homeostasis; Diseases

Science Insights, 2022 February 28; Vol. 40, No. 3, pp.443-449.

(c) 2022 Insights Publisher. All rights reserved.

Creative Commons Non Commercial CC BY-NC: This article is distributed under the terms of the Creative Commons Attribution-NonCommercial 4.0 License which permits non-commercial use, reproduction and distribution of the work without further permission provided the original work is attributed by the Insights Publisher.

$\mathrm{T}$ HE human body contains between $10^{12}$ and $10^{14}$ gut microbiota, with an average mass of roughly $1.5 \mathrm{~kg}(1,2)$ and approximately 6-10 groups (3,000 species) of bacteria $(3,4)$. Infants populate the gut with microorganisms immediately after birth, and this process continues until the gut microbiota stabilizes to a commensal state (5). The host benefits from the gut microbiome. The gut microbiota is critical for human development (6), intestinal barrier function (7), immunological modulation (8), material metabolism (9), nutrient absorption (10), toxin excretion (11) and disease incidence and development (12). Disruptions in the gut microbiota can result in a variety of disorders, including obesity, cirrhosis of the liver, diabetes, cardiovascular disease, and autism. The primary role of the gut microbiota is to aid the host metabolism by optimizing the utilization of energy and nutrients, providing nutrition to intestinal epithelial cells, enhancing host immunological function, and assisting the host in resisting harmful bacteria (13).

Studies have demonstrated that the gut microbiota's metabolic role is critical, and its efficiency much exceeds that of the liver. For instance, the gut microbiota not only influences the fatty acid content of the retina and the density of the eye lens, bone, and intestinal blood vessels $(14,15)$; but also delivers vital nutrients (biotin, vitamin $\mathrm{K}$, butyric acid, and so on) and digests edible cellulose (16). The immune system's regular operation (fighting against bacterial infections) is dependent on the gut microbiota (17). Simultaneously, the gut microbiota plays a critical role in the maturation of the "mucosal immune system" and "systemic immune system" $(18,19)$. The composition and 
metabolites of the gut microbiota have been shown to have a significant effect on immunological and inflammatory responses in experimental experiments. When the immune system of the gut fails, chronic enteritis disorders such as Crohn's disease and ulcerative colitis can result (20). However, because the commensal gut microbiota is so diverse, it is difficult to distinguish between commensal and opportunistically pathogenic bacteria, immunological regulation of the gut microbiota colonization response is a complicated system.

\section{Gut Microbiota Induces Regulatory T Cells}

$\mathrm{CD}^{+}{ }^{+} \mathrm{T}$ cells, particularly $\mathrm{Th} 1$, Th17, and regulatory $\mathrm{T}$ cells $\left(\mathrm{CD}^{+}, \mathrm{CD} 25^{+}, \mathrm{Foxp}^{+}\right)$, are crucial for maintaining intestinal immunological homeostasis in the presence of commensal microflora that are not pathogenic (21). Only when a complex microbial flora exists in the stomach will more Th1 and Th17 regulatory $\mathrm{T}$ cells be generated, and their numbers are extremely low in germ-free animals $(8,22)$. A single bacterial population, such as segmented filamentous, can also trigger regulatory $\mathrm{T}$ cell responses, such as Th17 cell responses $(23,24)$. Additionally, Foxp3+ regulatory $\mathrm{T}$ cells persist in the intestinal mucosa and lymphoid tissues linked with the intestinal mucosa, which is critical for the intestinal inflammatory response (25). Mucosal regulatory $\mathrm{T}$ cells can be constantly created by retinoic acid-induced particular axonal cells $(26,27)$. Clostridia in the gut play a critical role in the development of mucosal and systemic immune systems (28). Experiments were undertaken to compare germ-free and germ-free mice colonized with ASF (altered Schaedler flora), and it was discovered that germ-free animals colonized with ASF activate and regenerate immunological regulatory $\mathrm{T}$ cells in the colonic lamina propria mucosa $(29,30)$ Without mucosal Th17 or Th1 cell responses, regulatory $\mathrm{T}$ cell induction is critical for $\mathrm{CD}^{+} \mathrm{T}$ cell homeostasis $(31,32)$. MyD88, a Toll-like receptor adaptor, and Ticam-1 are necessary for effective $\mathrm{T}$ cell activation regulation (33).

Additionally, interleukin-10 receptor (IL-10R) signaling is required for the formation of $\mathrm{CD}^{+} \mathrm{T}$ cell homeostasis in the gut. IL-10R signaling, on the other hand, cannot impact the production and activation of regulatory $\mathrm{T}$ cells, as activation of regulatory $\mathrm{T}$ cells can result in mucosal immunological bias (to carry out Th1 and Th17 cell responses), which requires wild-type regulatory $\mathrm{T}$ cells to compensate. As a result, the activation of regulatory $\mathrm{T}$ cells by the symbiotic gut microbiota is critical (34). Whether functional regulatory T cells are activated or not, ASF has a constant composition and non-invasive features. This data suggests that in the absence of sex $\mathrm{T}$ cell responses, the immunological bias was toward Th17 cell responses in non-commensal regulatory $\mathrm{T}$ cells, a finding consistent with the absence of filamentous bacteria in the gut (35). Thus, symbiotic stimulation of intestinal regulatory $\mathrm{T}$ cells is a critical strategy for maintaining intestinal immunological homeostasis following microbial colonization of the gut, laying the groundwork for the creation of a cascade of immune responses.

\section{Gut Microbiota Induces IgA Protein}

Immunoglobulin $\mathrm{A}(\operatorname{Ig} \mathrm{A})$ is a kind of antibody that is required for mucosal immunity. IgA is produced in greater quantities than other types of antibodies in the mucosa (36), and approximately
3-5 $\mathrm{g}$ of $\operatorname{IgA}$ is secreted into the gut daily (37), accounting for $15 \%$ of all immunoglobulins produced by the human body (38). Numerous immunological illnesses can be caused by abnormal IgA, including IgA nephropathy, celiac disease, Henoch-Schönlein purpura, linear IgA bullous skin diseases, and IgA pemphigus (39). Given the difficulty of curing these disorders, it is critical to understand the mechanism through which the gut microbiota affects $\operatorname{Ig} \mathrm{A}$.

It has been demonstrated through the use of germ-free animals with commensal bacteria in the gut that the mucosa is extremely adaptable to commensal microbes (40). Although the complete functional importance of these modifications is unknown, when commensal microorganisms are present, the total intestinal IgA released by the intestinal mucosa accounts for more than $70 \%$ of the total immune proteins secreted in the human body (41-43). However, it is unknown whether the secreted IgA simply inhibits the growth of commensal microorganisms in the gut or whether commensal microorganisms that express IgA are prevented from penetrating the superficial epithelium. Like other pathogenic bacteria, commensal microorganisms express substances that can be detected by systemic immune system Toll-like receptors $(44,45)$. While commensal microbes and their metabolites can stimulate B and T cells, they do not induce pathogenic infection features (neutrophil infiltration and usual inflammatory responses) (46). By administering Enterobacter cloacae and other commensal microorganisms to mice, an experiment demonstrated how commensal microbes reach intestinal dendritic cells to stimulate IgA synthesis (47). The stomachs of C5BL/6 wild-type mice were injected with a specific dose of E. cloacae, and after culture for a length of time, the bacteria were retrieved by washing the mesenteric lymph node (MLN) (48). Between 200 and 800 species were maintained, and no bacteria were detected in the spleen cells or other systemic tissues of mice (49). Following bacterial culture, it was determined that living commensal bacteria existed in dendritic cells (DCs) but not in macrophages via fluorescence-activated cell sorting, as macrophages can efficiently kill infiltrating commensal microorganisms (50), whereas dendritic cells are relatively inefficient at killing bacteria (51).

Salmonella typhimurium was injected into mice and cultivated for 18 hours, and it was discovered that Salmonella could be isolated from spleen cells, dendritic cells, and macrophages in intestinal lymph nodes (52). Commensal bacteria, on the other hand, are distinct from pathogens. Because macrophages can effectively eliminate symbiotic bacteria, just a few commensal bacteria can survive in dendritic cells (52). The intestinal examination of mice revealed that commensal bacteria were carried by dendritic cells and moved to the intestinal lymph nodes with them, and that dendritic cells were activated following Enterobacter cloacae phagocytosis (53). IgA was selectively produced in the mucous membrane and serum of mice following repeated intragastric instillation with Enterobacter cloacae, whereas non-mucosal and serum IgA were not found (54). B cells release $\mathrm{IgA}$, and $\operatorname{IgA}^{+} \mathrm{B}$ cells are induced exclusively in the presence of dendritic cells containing Enterobacter cloacae (55). Thus, while most symbiotic microorganisms are rapidly killed by macrophages, a few can enter dendritic cells and survive for a few days, when dendritic cells containing symbiotic microor- 
ganisms can selectively induce large amounts of $\operatorname{IgA}$ to defend against commensal microorganisms penetrating the mucosa Adults treated with prebiotics (oligosaccharides) indicated that: (i) Prebiotics have the potential to alter the makeup of gut commensal microorganisms; and (ii) The rise in fecal $\operatorname{IgA}$ is directly tied to gut commensal microbes (56). These findings demonstrate that the gut microbiota has a role in IgA modulation, implying novel therapeutic strategies for IgA-related illnesses.

\section{Effects of Gut Microbiota on the Expression of Immune Antimicrobial Peptides}

Almost all plants and animals contain antimicrobial peptides (AMPs). In mammals, AMPs are expressed by both epithelial cells in the steady state and immune cells during inflammatory responses (57, 58). Antimicrobial peptides are positively charged polypeptides that have the ability to kill microorganisms by interfering with the integrity of their cell membranes $(59,60)$. Apart from their antibacterial properties, antimicrobial peptides have pro/anti-inflammatory properties in the immune system (61, 62). It has been reported that antimicrobial peptide cathelicidins play a significant role in the development of autoimmune diseases (systemic lupus erythematosus, vasculitis, and psoriasis, among others) (63), which are all caused by excessive cathelicidin expression on neutrophils, and the onset of non-obese autoimmune diseases follows the same mechanism $(64,65)$. Via injecting the antimicrobial peptide cathelicidins into normal mice and non-obese diabetic mice, we discovered that the gut microbiota regulates the production of cathelicidins in mouse pancreatic endocrine cells by regulating the synthesis of short-chain fatty acids (66). It can maintain immunological homeostasis and exert positive immune regulation on pancreatic macrophages and common dendritic cells via the generation of regulatory $\mathrm{T}$ cells (67). Thus, the concentration of pancreatic antimicrobial peptide cathelicidins was found to be extremely low in female non-obese diabetic mice with faulty short-chain fatty acid synthesis, indicating that the mice will develop pancreatitis and autoimmune disorders (68). Cathelicidins, which are antibacterial peptides, exhibit direct chemotaxis toward a variety of innate immune cells (neutrophils, macrophages, common dendritic cells, etc.). When antimicrobial peptide cathelicidins fight an infection, they first employ innate immune cells and then rely on their viability to avoid immuno-pathological tissue damage (69).

Endocrine cells use short-chain unsaturated fatty acids and their associated receptors GPR41 and GPR43 to synthesize antimicrobial peptide cathelicidins. Beta cells express these receptors (70). By virtue of short-chain fatty acids generating an immunological milieu in the pancreas, the gut microbiota controls autoimmune disorders. Due to the fact that the gut microbiota can influence the connection between the colonic epithelium and the intestinal immune system, it plays a role in a variety of autoimmune illnesses, including type 1 diabetes (T1DM) (71). By decreasing the number of butyrate-producing bacteria in the gut microbiota of type 1 diabetic patients, the condition can be improved (72). The gut microbiota of male mice was transferred into the intestines of female mice with non-obese diabetes in an experiment, and it was discovered to have a protective effect against diabetes; at the same time, the proportion of butyr- ate-producing bacteria in the intestines of female mice with non-obese diabetes increased. This finding implies that by supplementing with short-chain fatty acids, the gut microbiota may be able to modify non-obese diabetes mellitus (73). The gut microbiota has the ability to regulate the production of antimicrobial peptides via the short-chain fatty acid synthesis pathway, hence preserving immunological homeostasis and preventing the development of autoimmune disorders.

\section{Impact of Gut Microbiota on IgE}

$\mathrm{IgA}$ production is dependent on the gut bacteria, whereas $\operatorname{IgE}$ production is the inverse. Although germ-free mice secrete more IgE than the reference level, the amount of IgE falls with commensal bacterium colonization $(74,75)$. Within one week after weaning, germ-free mice developed 1,000-10,000 times the level of IgE compared to traditionally reared 64-day-old mice (76). It is worth mentioning that when only one or two species were colonized in the intestinal tract, even a large dose of a single strain $\left(10^{9}-10^{10} \mathrm{CFU}\right)$ administered via gavage was unable to suppress excessive IgE expression (77). However, when fed to germ-free mice, a more diversified intestinal flora, such as seven to forty distinct groups of intestinal flora, can restore normal $\mathrm{IgE}$ levels in mice (78). Additionally, high levels of germ-free murine $\mathrm{IgE}$ are dependent on $\mathrm{CD} 4^{+} \mathrm{T}$ cells, IL-4, and mucosal lymphoid tissue, but are unaffected by dietary antigens (79). The decrease in IgE levels induced by microorganisms is dependent on direct interaction between $\mathrm{B}$ cells and microorganisms and on the intracellular myd88 signaling pathway (80).

Although the explanation for the increased IgE levels in sterile mice is unknown, it is determined that the increased $\operatorname{IgE}$ levels encourage the occurrence of Th2-type inflammatory responses $(81,82)$. Under antibiotic stress or sterile culture conditions, reducing the amount of commensal bacteria colonizing mice enhanced the number of IgE antibody-dependent circulating basophils and the activation of Th2-type T cells. Increased IgE expression also increases basophil IL-3 expression, promoting the maturation of basophil precursors $(83,84)$, and the state of mast cells is also regulated by IgE levels (85), and increased $\mathrm{IgE}$ expression under sterile conditions results in an increase in the amount of IgE bound to the surface of mast cells, resulting in systemic allergic reactions (86). As a result, the gut microbiota not only affects the production of intestinal $\operatorname{IgA}$, but also the expression of $\mathrm{IgE}$.

\section{Conclusions}

The gut microbiota is critical for the development of gastrointestinal and immunological illnesses, as commensal microorganisms can send signals that encourage appropriate immune responses and can influence subsequent immune responses. However, the method by which commensal bacteria in the gut interact with the immune system remains unknown. It is possible that commensal microorganisms communicate with the immune system via the chemicals they create. Once these mechanisms are elucidated, the therapy of immune-associated disorders will focus on controlling these bacteria through the examination of the gut microbiota and the use of prebiotics and probiotics. Additionally, the gut microbiota of healthy persons can be used to treat certain disorders. Meanwhile, for symbiotic bacte- 
ria, the host is merely a complicated habitat that varies between healthy and diseased states. The challenge is to determine whether sickness directly affects symbiotic microorganisms or whether disease directly affects the host environment, causing the symbiotic bacteria to adapt to the new environment. We can only maintain a mutualistic relationship with the gut microbiota if we comprehend the relationship between the symbiotic microbial structure and the host.

\section{References}

1. Sender R, Fuchs S, Milo R. Revised estimates for the number of human and bacteria cells in the body. PLoS Biol 2016; 14(8):e1002533. DOI: https://doi.org/10.1371/journal.pbio.1002533

2. Thursby E, Juge N. Introduction to the human gut microbiota. Biochem J 2017; 474(11):1823-1836. DOI: https://doi.org/10.1042/BCJ20160510

3. Kho ZY, Lal SK. The human gut microbiome - A potential controller of wellness and disease. Front Microbiol 2018; 9:1835. DOI: https://doi.org/10.3389/fmicb.2018.01835

4. Rowland I, Gibson G, Heinken A, Scott K, Swann J, Thiele I, Tuohy K. Gut microbiota functions: metabolism of nutrients and other food components. Eur $\mathrm{J}$ Nutr 2018; 57(1):1-24. DOI: https://doi.org/10.1007/s00394-017-1445-8

5. Milani C, Duranti S, Bottacini F, Casey E, Turroni F, Mahony J, Belzer C, Delgado Palacio S, Arboleya Montes S, Mancabelli L, Lugli GA, Rodriguez JM, Bode L, de Vos W, Gueimonde M, Margolles A, van Sinderen $D$, Ventura $M$. The first microbial colonizers of the human gut: Composition, activities, and health implications of the infant gut microbiota. Microbiol Mol Biol Rev 2017; 81(4):e00036-17. DOI: https://doi.org/10.1128/MMBR.00036-17

6. Dominguez-Bello MG, Godoy-Vitorino F, Knight R, Blaser MJ. Role of the microbiome in human development. Gut 2019; 68(6):1108-1114. DOI: https://doi.org/10.1136/gutjnl-2018-317503

7. Takiishi T, Fenero CIM, Câmara NOS. Intestinal barrier and gut microbiota: Shaping our immune responses throughout life. Tissue Barriers 2017; 5(4):e1373208. DOI: https://doi.org/10.1080/21688370.2017.1373208

8. Wu HJ, Wu E. The role of gut microbiota in immune homeostasis and autoimmunity. Gut Microbes 2012; 3(1):4-14. DOI: https://doi.org/10.4161/gmic.19320

9. Cani PD, Moens de Hase E, Van Hul M. Gut microbiota and host metabolism: From proof of concept to therapeutic intervention. Microorganisms 2021; 9(6):1302. DOI: https://doi.org/10.3390/microorganisms9061302

10. Krajmalnik-Brown R, Ilhan ZE, Kang DW, DiBaise JK. Effects of gut microbes on nutrient absorption and energy regulation. Nutr Clin Pract 2012; 27(2):201-14. DOI: https://doi.org/10.1177/0884533611436116

11. Claus SP, Guillou H, Ellero-Simatos $S$. The gut microbiota: a major player in the toxicity of environ-

mental pollutants? NPJ Biofilms Microbiomes 2016; 2:16003. DOI:

https://doi.org/10.1038/npibiofilms.2016.3. Erratum in: NPJ Biofilms Microbiomes 2017; 3:17001.

12. Chen $Y$, Zhou J, Wang L. Role and mechanism of gut microbiota in human disease. Front Cell Infect Microbiol 2021; 11:625913. DOI: https://doi.org/10.3389/fcimb.2021.625913

13. Pickard JM, Zeng MY, Caruso R, Núñez G. Gut microbiota: Role in pathogen colonization, immune responses, and inflammatory disease. Immunol Rev 2017; 279(1):70-89. DOI: https://doi.org/10.1111/imr.12567

14. Napolitano P, Filippelli M, Davinelli S, Bartollino S, dell'Omo R, Costagliola C. Influence of gut microbiota on eye diseases: An overview. Ann Med 2021; 53(1):750-761. DOI: https://doi.org/10.1080/07853890.2021.1925150

15. Parolini C. Effects of fish n-3 PUFAs on intestinal microbiota and immune system. Mar Drugs 2019; 17(6):374. DOI: https://doi.org/10.3390/md17060374

16. Morowitz MJ, Carlisle EM, Alverdy JC. Contributions of intestinal bacteria to nutrition and metabolism in the critically ill. Surg Clin North Am 2011; 91(4):771-785, viii. DOI: https://doi.org/10.1016/i.suc.2011.05.001

17. Belkaid Y, Hand TW. Role of the microbiota in immunity and inflammation. Cell 2014; 157(1):121-41. DOI: https://doi.org/10.1016/j.cell.2014.03.011

18. Lazar V, Ditu LM, Pircalabioru GG, Gheorghe I, Curutiu C, Holban AM, Picu A, Petcu L, Chifiriuc MC. Aspects of gut microbiota and immune system interactions in infectious diseases, immunopathology, and cancer. Front Immunol 2018; 9:1830. DOI: https://doi.org/10.3389/fimmu.2018.01830

19. Peng J, Tang Y, Huang Y. Gut health: The results of microbial and mucosal immune interactions in pigs. Anim Nutr 2021; 7(2):282-294. DOI: https://doi.org/10.1016/j.aninu.2021.01.001

20. Sankarasubramanian J, Ahmad R, Avuthu N, Singh AB, Guda C. Gut microbiota and metabolic specificity in ulcerative colitis and Crohn's disease. Front Med (Lausanne) 2020; 7:606298. DOI: https://doi.org/10.3389/fmed.2020.606298

21. Okeke EB, Uzonna JE. The pivotal role of regulatory $T$ cells in the regulation of innate immune cells. Front Immunol 2019; 10:680. DOI: https://doi.org/10.3389/fimmu.2019.00680 
22. Kennedy EA, King KY, Baldridge MT. Mouse microbiota models: comparing germ-free mice and antibiotics treatment as tools for modifying gut bacteria. Front Physiol 2018; 9:1534. DOI: https://doi.org/10.3389/fphys.2018.01534

23. Hand T, Belkaid Y. Microbial control of regulatory and effector $\mathrm{T}$ cell responses in the gut. Curr Opin Immunol 2010; 22(1):63-72. DOI: https://doi.org/10.1016/i.coi.2010.01.008

24. Pandiyan P, Bhaskaran N, Zou M, Schneider E, Jayaraman S, Huehn J. Microbiome dependent regulation of Tregs and Th17 cells in mucosa. Front Immunol 2019; 10:426. DOI: https://doi.org/10.3389/fimmu.2019.00426

25. Cosovanu C, Neumann C. The many functions of Foxp3+ regulatory T cells in the intestine. Front Immunol 2020; 11:600973. DOI: https://doi.org/10.3389/fimmu.2020.600973

26. Workman CJ, Szymczak-Workman AL, Collison LW, Pillai MR, Vignali DA. The development and function of regulatory T cells. Cell Mol Life Sci 2009; 66(16):2603-22. DOI: https://doi.org/10.1007/s00018-009-0026-2

27. Oliveira LM, Teixeira FME, Sato MN. Impact of retinoic acid on immune cells and inflammatory diseases. Mediators Inflamm 2018; 2018:3067126. DOI: https://doi.org/10.1155/2018/3067126

28. Lopetuso LR, Scaldaferri F, Petito V, Gasbarrini A. Commensal Clostridia: leading players in the maintenance of gut homeostasis. Gut Pathog 2013; 5(1):23. DOI: https://doi.org/10.1186/1757-4749-5-23

29. Dewhirst FE, Chien CC, Paster BJ, Ericson RL, Orcutt RP, Schauer DB, Fox JG. Phylogeny of the defined murine microbiota: Altered Schaedler flora. Appl Environ Microbiol 1999; 65(8):3287-3292. DOI: https://doi.org/10.1128/AEM.65.8.3287-3292.1999

30. Wymore Brand M, Wannemuehler MJ, Phillips GJ, Proctor A, Overstreet AM, Jergens AE, Orcutt RP, Fox JG. The altered Schaedler flora: Continued applications of a defined murine microbial community. ILAR J 2015; 56(2):169-78. DOI: https://doi.org/10.1093/ilar/ilv012

31. Harrison OJ, Powrie FM. Regulatory T cells and immune tolerance in the intestine. Cold Spring Harb Perspect Biol 2013; 5(7):a018341. DOI: https://doi.org/10.1101/cshperspect.a018341. Erratum in: Cold Spring Harb Perspect Biol 2013; 5(8):a021022

32. Pandiyan P, Younes SA, Ribeiro SP, Talla A, McDonald $D$, Bhaskaran N, Levine AD, Weinberg A, Sekaly RP. Mucosal regulatory T cells and T helper 17 cells in HIV-associated immune activation. Front Immunol 2016; 7:228. DOI: https://doi.org/10.3389/fimmu.2016.00228

33. Seya T, Oshiumi H, Sasai M, Akazawa T, Matsumoto M. TICAM-1 and TICAM-2: Toll-like receptor adapters that participate in induction of type 1 interferons. Int $\mathrm{J}$ Biochem Cell Biol 2005; 37(3):524-529. DOI: https://doi.org/10.1016/j.biocel.2004.07.018

34. Shouval DS, Ouahed J, Biswas A, Goettel JA, Horwitz BH, Klein C, Muise AM, Snapper SB. Interleukin 10 receptor signaling: master regulator of in- testinal mucosal homeostasis in mice and humans. Adv Immunol 2014; 122:177-210. DOI:

https://doi.org/10.1016/B978-0-12-800267-4.00005-5

35. Chaudhry A, Samstein RM, Treuting P, Liang Y, Pils MC, Heinrich JM, Jack RS, Wunderlich FT, Brüning JC, Müller W, Rudensky AY. Interleukin-10 signaling in regulatory $T$ cells is required for suppression of Th17 cell-mediated inflammation. Immunity 2011 ; 34(4):566-578. DOI: https://doi.org/10.1016/j.immuni.2011.03.018

36. Corthésy $B$. Multi-faceted functions of secretory $\lg A$ at mucosal surfaces. Front Immunol 2013; 4:185. DOI: https://doi.org/10.3389/fimmu.2013.00185

37. Pietrzak B, Tomela K, Olejnik-Schmidt A, Mackiewicz A, Schmidt M. Secretory IgA in intestinal mucosal secretions as an adaptive barrier against microbial cells. Int J Mol Sci 2020; 21(23):9254. DOI: https://doi.org/10.3390/ijms21239254

38. Reinholdt J, Husby S. IgA and Mucosal Homeostasis. In: Madame Curie Bioscience Database [Internet]. Austin (TX): Landes Bioscience; 2000-2013. Available from: https://www.ncbi.nlm.nih.gov/books/NBK6628/

39. Papista C, Berthelot L, Monteiro RC. Dysfunctions of the Iga system: a common link between intestinal and renal diseases. Cell Mol Immunol 2011; 8(2):126-134. DOI: https://doi.org/10.1038/cmi.2010.69

40. Zheng D, Liwinski T, Elinav E. Interaction between microbiota and immunity in health and disease. Cell Res 2020; 30(6):492-506. DOI: https://doi.org/10.1038/s41422-020-0332-7

41. Corthésy $B$. Multi-faceted functions of secretory $\lg A$ at mucosal surfaces. Front Immunol 2013; 4:185. DOI: https://doi.org/10.3389/fimmu.2013.00185

42. Mantis NJ, Rol N, Corthésy B. Secretory IgA's complex roles in immunity and mucosal homeostasis in the gut. Mucosal Immunol 2011; 4(6):603-611. DOI: https://doi.org/10.1038/mi.2011.41

43. Pabst O, Slack E. IgA and the intestinal microbiota: The importance of being specific. Mucosal Immunol 2020; 13(1):12-21. DOI: https://doi.org/10.1038/s41385-019-0227-4

44. Macpherson AJ. $\operatorname{Ig} A$ adaptation to the presence of commensal bacteria in the intestine. Curr Top Microbiol Immunol 2006; 308:117-136. DOI: https://doi.org/10.1007/3-540-30657-9 5

45. Macpherson AJ, Slack E. The functional interactions of commensal bacteria with intestinal secretory $\lg \mathrm{A}$. Curr Opin Gastroenterol 2007; 23(6):673-678. DOI: https://doi.org/10.1097/MOG.0b013e3282f0d012

46. Tanoue T, Umesaki Y, Honda K. Immune responses to gut microbiota-commensals and pathogens. Gut Microbes 2010; 1(4):224-233. DOI: https://doi.org/10.4161/gmic.1.4.12613

47. Macpherson AJ, Geuking MB, McCoy KD. Immune responses that adapt the intestinal mucosa to commensal intestinal bacteria. Immunology 2005; 115(2):153-162. DOI: https://doi.org/10.1111//.1365-2567.2005.02159.x

48. Shaikh H, Vargas JG, Mokhtari Z, Jarick KJ, Ulbrich M, Mosca JP, Viera EA, Graf C, Le DD, Heinze KG, 
Büttner-Herold M, Rosenwald A, Pezoldt J, Huehn J, Beilhack $A$. Mesenteric lymph node transplantation in mice to study immune responses of the gastrointestinal tract. Front Immunol 2021; 12:689896. DOI: https://doi.org/10.3389/fimmu.2021.689896

49. Barnes PD, Bergman MA, Mecsas J, Isberg RR. Yersinia pseudotuberculosis disseminates directly from a replicating bacterial pool in the intestine. J Exp Med 2006; 203(6):1591-1601. DOI:

https://doi.org/10.1084/jem.20060905. Erratum in: J Exp Med 2006; 203(7):1829.

50. Kang B, Alvarado LJ, Kim T, Lehmann ML, Cho H, He J, Li P, Kim BH, Larochelle A, Kelsall BL. Commensal microbiota drive the functional diversification of colon macrophages. Mucosal Immunol 2020;

13(2):216-229. DOI:

https://doi.org/10.1038/s41385-019-0228-3

51. Mbongue J, Nicholas D, Firek A, Langridge W. The role of dendritic cells in tissue-specific autoimmunity. J Immunol Res 2014; 2014:857143. DOI: https://doi.org/10.1155/2014/857143

52. Niedergang F, Sirard JC, Blanc CT, Kraehenbuhl JP. Entry and survival of Salmonella typhimurium in dendritic cells and presentation of recombinant antigens do not require macrophage-specific virulence factors. Proc Natl Acad Sci USA 2000; 97(26):14650-14655. DOI: https://doi.org/10.1073/pnas.97.26.14650

53. Tezuka H, Ohteki T. Regulation of IgA production by intestinal dendritic cells and related cells. Front Immunol 2019; 10:1891. DOI: https://doi.org/10.3389/fimmu.2019.01891

54. Zhang $\mathrm{Y}$, Pacheco S, Acuna CL, Switzer KC, Wang Y, Gilmore X, Harriman GR, Mbawuike IN. Immunoglobulin A-deficient mice exhibit altered T helper 1 -type immune responses but retain mucosal immunity to influenza virus. Immunology 2002; 105(3):286-294. DOI:

https://doi.org/10.1046/i.0019-2805.2001.01368.x

55. Macpherson AJ, McCoy KD, Johansen FE, Brandtzaeg $P$. The immune geography of $\lg A$ induction and function. Mucosal Immunol 2008; 1(1):11-22. DOI: https://doi.org/10.1038/mi.2007.6

56. Hasan N, Yang H. Factors affecting the composition of the gut microbiota, and its modulation. PeerJ 2019; 7:e7502. DOI: https://doi.org/10.7717/peeri.7502

57. Diamond G, Beckloff N, Weinberg A, Kisich KO. The roles of antimicrobial peptides in innate host defense. Curr Pharm Des 2009; 15(21):2377-2392. DOI: https://doi.org/10.2174/138161209788682325

58. Gallo RL, Hooper LV. Epithelial antimicrobial defence of the skin and intestine. Nat Rev Immunol 2012; 12(7):503-516. DOI: https://doi.org/10.1038/nri3228

59. Lei J, Sun L, Huang S, Zhu C, Li P, He J, Mackey V, Coy $\mathrm{DH}, \mathrm{He} \mathrm{Q}$. The antimicrobial peptides and their potential clinical applications. Am J Transl Res 2019; 11(7):3919-3931.

60. Bahar AA, Ren D. Antimicrobial peptides. Pharmaceuticals (Basel) 2013; 6(12):1543-1575. DOI: https://doi.org/10.3390/ph6121543

61. Méndez-Samperio P. Recent advances in the field of antimicrobial peptides in inflammatory diseases. Adv Biomed Res 2013; 2:50. DOI:

https://doi.org/10.4103/2277-9175.114192

62. Shin MK, Hwang IW, Kim Y, Kim ST, Jang W, Lee S, Bang WY, Bae CH, Sung JS. Antibacterial and anti-inflammatory effects of novel peptide toxin from the spider Pardosa astrigera. Antibiotics (Basel) 2020; 9(7):422. DOI: https://doi.org/10.3390/antibiotics9070422

63. Kahlenberg JM, Kaplan MJ. Little peptide, big effects: the role of LL-37 in inflammation and autoimmune disease. J Immunol 2013; 191(10):4895-4901. DOI: https://doi.org/10.4049/jimmunol.1302005

64. Navegantes KC, de Souza Gomes R, Pereira PAT, Czaikoski PG, Azevedo CHM, Monteiro MC. Immune modulation of some autoimmune diseases: The critical role of macrophages and neutrophils in the innate and adaptive immunity. J Transl Med 2017; 15(1):36. DOI: https://doi.org/10.1186/s12967-017-1141-8

65. Liang W, Diana J. The dual role of antimicrobial peptides in autoimmunity. Front Immunol 2020; 11:2077. DOI: https://doi.org/10.3389/fimmu.2020.02077

66. Sun J, Furio L, Mecheri R, van der Does AM, Lundeberg E, Saveanu L, Chen Y, van Endert $P$, Agerberth B, Diana J. Pancreatic $\beta$-cells limit autoimmune diabetes via an immunoregulatory antimicrobial peptide expressed under the influence of the gut microbiota. Immunity 2015; 43(2):304-317. DOI: https://doi.org/10.1016/i.immuni.2015.07.013

67. Francisco LM, Sage PT, Sharpe AH. The PD-1 pathway in tolerance and autoimmunity. Immunol Rev 2010; 236:219-242. DOI: https://doi.org/10.1111/j.1600-065X.2010.00923.x

68. Liu JL, Segovia I, Yuan XL, Gao ZH. Controversial roles of gut microbiota-derived short-chain fatty acids (SCFAs) on pancreatic $\beta$-cell growth and insulin secretion. Int J Mol Sci 2020; 21(3):910. DOI: https://doi.org/10.3390/ijms21030910

69. Chaplin DD. Overview of the immune response. J Allergy Clin Immunol 2010; 125(2 Suppl 2):S3-S23. DOI: https://doi.org/10.1016/j.jaci.2009.12.980

70. Priyadarshini M, Kotlo KU, Dudeja PK, Layden BT. Role of short chain fatty acid receptors in intestinal physiology and pathophysiology. Compr Physiol 2018; 8(3):1091-1115. DOI: https://doi.org/10.1002/cphy.c170050

71. Jiao $Y$, Wu L, Huntington ND, Zhang X. Crosstalk between gut microbiota and innate immunity and its implication in autoimmune diseases. Front Immunol 2020; 11:282. DOI: https://doi.org/10.3389/fimmu.2020.00282

72. Zhou H, Sun L, Zhang S, Zhao X, Gang X, Wang G. Evaluating the causal role of gut microbiota in type 1 diabetes and its possible pathogenic mechanisms. Front Endocrinol (Lausanne) 2020; 11:125. DOI: https://doi.org/10.3389/fendo.2020.00125

73. Harsch IA, Konturek PC. The role of gut microbiota in obesity and type 2 and type 1 diabetes mellitus: New insights into "old" diseases. Med Sci (Basel) 2018; 6(2):32. DOI: https://doi.org/10.3390/medsci6020032

74. Schwarzer M, Hermanova P, Srutkova D, Golias J, 
Hudcovic T, Zwicker C, Sinkora M, Akgün J, Wiedermann U, Tuckova L, Kozakova H,

Schabussova I. Germ-free mice exhibit mast cells with impaired functionality and gut homing and do not develop food allergy. Front Immunol. 2019; 10:205. DOI: https://doi.org/10.3389/fimmu.2019.00205

75. Cahenzli J, Köller Y, Wyss M, Geuking MB, McCoy $\mathrm{KD}$. Intestinal microbial diversity during early-life colonization shapes long-term IgE levels. Cell Host Microbe 2013; 14(5):559-570. DOI: https://doi.org/10.1016/i.chom.2013.10.004

76. Russell SL, Gold MJ, Willing BP, Thorson L, McNagny KM, Finlay BB. Perinatal antibiotic treatment affects murine microbiota, immune responses and allergic asthma. Gut Microbes 2013; 4(2):158-164. DOI: https://doi.org/10.4161/gmic.23567

77. Ansotegui IJ, Melioli G, Canonica GW, Caraballo L, Villa E, Ebisawa M, Passalacqua G, Savi E, Ebo D, Gómez RM, Luengo Sánchez O, Oppenheimer JJ, Jensen-Jarolim E, Fischer DA, Haahtela T, Antila M, Bousquet JJ, Cardona V, Chiang WC, Demoly PM, DuBuske LM, Ferrer Puga M, Gerth van Wijk R, González Díaz SN, Gonzalez-Estrada A, Jares E, Kalpaklioğlu AF, Kase Tanno L, Kowalski ML, Ledford DK, Monge Ortega OP, Morais Almeida M, Pfaar O, Poulsen LK, Pawankar R, Renz HE, Romano AG, Rosário Filho NA, Rosenwasser L, Sánchez Borges MA, Scala E, Senna GE, Sisul JC, Tang MLK, Thong BY, Valenta R, Wood RA, Zuberbier T. IgE allergy diagnostics and other relevant tests in allergy, a World Allergy Organization position paper. World Allergy Organ J 2020; 13(2):100080. DOI: https://doi.org/10.1016/j.waojou.2019.100080. Erratum in: World Allergy Organ J 2021; 14(7):100557.

78. Molloy J, Allen K, Collier F, Tang ML, Ward AC, Vuillermin $P$. The potential link between gut microbiota and IgE-mediated food allergy in early life. Int J Environ Res Public Health 2013;
10(12):7235-7256. DOI:

https://doi.org/10.3390/ijerph10127235

79. Berin MC, Sampson HA. Mucosal immunology of food allergy. Curr Biol 2013; 23(9):R389-R400. DOI: https://doi.org/10.1016/j.cub.2013.02.043

80. Thakur A, Mikkelsen H, Jungersen G. Intracellular pathogens: Host immunity and microbial persistence strategies. J Immunol Res 2019; 2019:1356540. DOI: https://doi.org/10.1155/2019/1356540

81. Dolence JJ, Kobayashi T, lijima K, Krempski J, Drake LY, Dent AL, Kita H. Airway exposure initiates peanut allergy by involving the IL-1 pathway and T follicular helper cells in mice. J Allergy Clin Immunol 2018; 142(4):1144-1158.e8. DOI: https://doi.org/10.1016/j.jaci.2017.11.020

82. Oettgen HC, Geha RS. IgE in asthma and atopy: Cellular and molecular connections. J Clin Invest 1999; 104(7):829-835. DOI: https://doi.org/10.1172/JCl8205

83. Hill DA, Siracusa MC, Abt MC, Kim BS, Kobuley D, Kubo M, Kambayashi T, Larosa DF, Renner ED, Orange JS, Bushman FD, Artis D. Commensal bacteria-derived signals regulate basophil hematopoiesis and allergic inflammation. Nat Med 2012; 18(4):538-546. DOI: https://doi.org/10.1038/nm.2657

84. Stone KD, Prussin C, Metcalfe DD. IgE, mast cells, basophils, and eosinophils. J Allergy Clin Immunol 2010; 125(2 Suppl 2):S73-S80. DOI: https://doi.org/10.1016/j.jaci.2009.11.017

85. Galli SJ, Tsai M. IgE and mast cells in allergic disease. Nat Med 2012; 18(5):693-704. DOI: https://doi.org/10.1038/nm.2755

86. Galli SJ. The mast cell-IgE paradox: From homeostasis to anaphylaxis. Am J Pathol 2016; 186(2):212-224. DOI: https://doi.org/10.1016/j.ajpath.2015.07.025

Received: December 02, 2021 ｜Ｒevised: December 28, 2021 ｜Ａccepted: January 10, 2022 